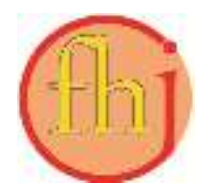

Faletehan Health Journal, 7 (3) (2020) 170-176

www. journal.Ippm-stikesfa.ac.id/ojs/index.php/FHJ

ISSN 2088-673X | e-ISSN 2597-8667

\title{
Pengaruh Pemberian Buklet Bacaan Islami Dengan Penerimaan Diri Pasien Hemodialisis
}

\author{
Agus Prasetyo ${ }^{1 *}$, Sodikin ${ }^{2}$, Sarwa $^{3}$ \\ 1,2,3 Program Studi Keperawatan, STIKES Al-Irsyad Al-Islamiyyah Cilacap, Indonesia \\ *Corresponding Author: prasetyoagus163@gmail.com
}

\begin{abstract}
Abstrak
Pasien yang menjalani hemodialisis mengalami berbagai masalah yang timbul akibat tidak berfungsinya ginjal. Pasien yang menjalani dialisis beresiko mengalami gangguan psikologis 1,5 - 3 kali lebih besar dibandingkan dengan penyakit kronis lainnya termasuk rendahnya tingkat penerimaan diri. Penelitian ini bertujuan untuk mengetahui bagaimanakah pengaruh pemberian booklet bacaan islami terhadap penerimaan diri pasien hemodialisis di RSI Fatimah Cilacap. Penelitian ini menggunakan desain quasi eksperiment: one goup pre test- post test design. Penelitian dilakukan pada 52 orang pasien yang menjalani hemodialysis, dengan tekhnik pengambilan sample purposive sampling. Alat ukur skala penerimaan diri pasien dalam penelitian ini menggunakan kuesioner yang terdiri dari 15 pertanyaan yang sudah dilakukan uji validitas dan reliabilitas. Analisis data menggunakan Sample paired T Test. Hasil penelitian didapatkan jenis kelamin terbanyak adalah perempuan (55,4\%), lama pasien menjalani hemodialisis terbanyak adalah dalam rentang 1 -3 tahun ( 57,7\%). Pasien yang menjalani hemodialisis terbanyak berpendidikan SD (46,2\%). Rerata usia pasien 49,86 tahun. Nilai Sig.(2-tailed) adalah sebesar $0.000<0.05$, atau dengan kata lain ada pengaruh pemberian buklet bacaan islami dengan penerimaan diri pasien hemodialisis di RSI Fatimah Cilacap.
\end{abstract}

Kata Kunci: Bacaan Islami, Hemodialisis, Penerimaan Diri

\section{The Effects of Giving Islamic Reading Booklets on Self-Acceptance of Hemodialysis Patients}

\begin{abstract}
Patients undergoing hemodialysis experience various problems arising from malfunctioning of the kidneys. They are 1.5 to 3 times more likely to experience psychological disorders than other chronic diseases including low levels of selfacceptance. This study aims to determine the effects of giving Islamic reading booklets on self-acceptance of hemodialysis patients at Islamic Hospital of Fatimah Cilacap. This study used a quasi-experimental design. The type of this research is one group pre-test-post-test design. The study was conducted to 52 patients undergoing hemodialysis at Islamic Hospital of Fatimah Cilacap with a purposive sampling technique. The instrument of patient self-acceptance scale in this study is a questionnaire that consists of 15 question items and had been tested for validity and reliability. The data analysis used sample paired $T$ Test. The results showed that most samples are female (55.4\%); most length of hemodialysis period is in the range of 1-3 years (57.7\%); most patients' educational background is elementary school (46.2\%); the mean of patients' age is 49.86 years. The Sig. (2-tailed) value is $0.000<0.05$; in other words, there are effects of giving Islamic reading booklets on hemodialysis patients' self-acceptance at Islamic Hospital of Fatimah Cilacap.

Keywords: Islamic Reading, Hemodialysis, Self-Acceptance
\end{abstract}


Faletehan Health Journal, 7 (3) (2020) 170-176

www. journal.Ippm-stikesfa.ac.id/ojs/index.php/FHJ

ISSN 2088-673X | 2597-8667

\section{Pendahuluan}

Pasien yang menjalani hemodialisis mengalami berbagai masalah yang timbul akibat tidak berfungsinya ginjal. Hal tersebut muncul setiap waktu sampai akhir kehidupan. Hal ini menjadi stressor fisik yang berpengaruh pada berbagai dimensi kehidupan pasien yang meliputi bio, psiko, sosio dan spiritual. Gangguan psikologis seperti rasa takut, cemas, dan depresi seringkali menyertai penyakit ginjal kronis.Jika kondisi ini berlangsung dalam jangka waktu yang panjang tanpa ada intervensi pada sisi psikologis mereka, maka bisa menjadikan mereka sulit untuk menerima dirinya, tidak menyenangi dirinya, mencemooh diri sendiri, merasa orang lain menjauhi dan menghina dirinya, tidak percaya pada perasaan dan sikapnya sendiri. Gejala-gejala yang ditunjukkan tersebut merupakan tanda rendahnya tingkat penerimaan diri. Penerimaan diri menurut Pannes (Elizabeth B. Hurlock 1973)adalah tingkat di mana ia menerimakarakteristik pribadinya, ia merasa mampu dan mau untuk hidup sebagaimana mestinya.

Perubahan fungsi secara progresif akibat penyakit ginjal yang diderita membuat pasien gagal ginjal mengalami berbagai stres psikologis. Perubahan keseharian akibat terapi yang harus dijalani, kewajiban melakukan kunjungan ke rumah sakit dan laboratorium secara rutin untuk pemeriksaan darah, dan perubahan finansial untuk biaya pengobatan membuat pasien mengalami stres dan membuat mereka tidak dapat menjalankan peran secara holistic. Keadaan lainya yang membuat kondisi psikologis pasien semakin berat adalah ancaman kematian, perasaan menjadi objek percobaan akibat seringnya diambil darah untuk pemeriksaan, stres akibat efek dari penyakit yang diderita, dan ketakutan akan diisolasi oleh lingkungan sekitar. Kelemahan fisik yang dirasakan seperti mual, muntah, nyeri, lemah otot, oedema adalah sebagian dari manifestasi klinik dari pasien yang menjalani hemodialisis. Faktor psikologis mampu mengarahkan pasien pada tingkat stress, cemasbahkan depresi dan putus asa dalam menghadapi penyakit yang di deritanya antara lain ketidakberdayaan serta kurangnya penerimaan diri pasien (Paramita 2013)

Penerimaan diri merupakan suatu sikap pada individu dengan menerima, menghargai dan mencintai kondisi fisik terhadap diri sendiri
(Elizabeth B. Hurlock 1973). (Permatasari 2012)menjelaskan bahwa seseorang yang menerima dirinya sendiri, mempunyai penilaian yang realistis terhadap adanya keterbatasan tanpa mencela dirinya dan sadar akan kemampuan serta secara bebas menggunakan kemampuannya tersebut dan tidak menyalahkan orang lain terhadap kekurangan yang dimiliknya. Menurut Shepard dalam (Kusuma 2013) penerimaan diri mengacu pada kepuasan seseorang atau kebahagiaan orang itu sendiri, dan merupakan salah satu hal yang penting untuk kesehatan mental yang baik. Penerimaan diri sendiri terdiri dari pemahaman diri sendiri, sebuah realita, subjektif, kesadaran yang merupakan salah satu kelebihan maupun kekurangan bagi individu tersebut.

Hasil penelitian yang dilakukan di Romania menunjukkan bahwa penerimaan diri berhubungan negatif dengan kecemasan psikologis dan somatik kecemasan serta otomatis pikiran negatif. Intervensi pada variabel inimelalui dukungan dapat menyebabkan untuk mengurangi kecemasan dan depresi, untuk mengubah gaya mengatasi dan, secara implisit, untuk meningkatkan kualitas hidup pasien. (Paloș and Vîșcu 2014) artinya penerimaan diri mempengaruhi tingkat kecemasan dan depresi hidup pasien.

Kegiatan membaca dapat digunakan sebagai intervensi dalam memenuhi kebutuhan akan pengetahuan dan mengubah pola pikir sehingga dapat merubah perilaku dan keadaan. Menurut (Dalman 2013)membaca adalahmenggali informasi dari teks, baik yang berupa tulisan maupun dari gambar atau diagrammaupun dari kombinasi itu semua. Adapun menurut (Tarigan and Guntur 2011)tujuan utama dalam membaca adalah untuk mencari serta memperoleh informasi, mencakup isi dan memahami makna dari bacaan.

Di dalam Islam, perintah membaca ada dalam wahyu pertama, walaupun ditujukan lewat Nabi Shallallahu Alaihi Wasallam yang tidak pandai membaca, ini menunjukkan pentingnya membaca. Al-Qur'an, selain sebagai kitab suci umat Islam, juga merupakan salah satu sumber utama dalam setiap disiplin keilmuan, menjawab setiap problematika yang tengah dihadapi para pemikir-pemikir, baik dari pemikir Islam, maupun pemikir Barat. Hal itu karena perintah membaca terkandung dalam Al-Qur'an yang mengandung konsep tentang aspek-aspek kehidupan termasuk di dalamnya adalah ilmu, sehingga wahyu menjadi 
sumber dan asas bagi aktivitas dan semua hal yang terjadi pada manusia di dunia.

Hasil studi pendahuluan yang peneliti lakukan dengan menggunakan wawancara dengan 3 orang pasien ruang hemodialisis RSI Fatimah Cilacap ditemukan bahwa dua orang mengatakan sedih dengan kondisi kesehatannya saat ini karena banyak merepotkan keluarga. Satu orang tidak bisa menerima kondisi tubuhnya yang banyak perubahan secara fisik. Hasil wawancara juga menunjukkan pasien sangat jarang membaca tentang kajian atau bacaan islami yang berhubungan dengan kondisi sehat dan sakit seseorang. Dengan prevalensi kasus gagal ginjal kronis yang terus meningkat, dirasakan perlu untuk memberikan sebuah intervensi berupa bacaan islami sebagai suatu sarana memenuhi kebutuhan informasi tentang hikmah sakit sehingga diharapkan penerimaan diri pasien akan kondisi kesehatannya dapat tercapai.

Berdasarkan latar belakang dan studi pendahuluan di atas maka peneliti tertarik untuk melakukan penelitian ini. Adapun tujuan umum penelitian adalah untuk mengetahui pengaruh pemberian booklet bacaan islami terhadap penerimaan diri (self aceptance) pasien hemodialisis di RSI Fatimah Cilacap.

\section{Metode Penelitian}

Penelitian ini menggunakan desain quasi eksperiment. Adapun jenis penelitian ini yaitu one goup pre test- post test design. Penelitian dilakukan pada 52 orang pasien yang menjalani hemodialisis di RSI Fatimah Cilacap dengan tekhnik pengambilan sample purposive sampling. Adapun kriteria inklusi pada penelitian ini adalah pasien gagal ginjal kronis yang telah menjalani hemodialisis di RSI Islam Fatimah Cilacap, beragama Islam, mempunyai keluhan fisik yang minimal, didampingi keluarga saat hemodialisis, mempunyai tekanan darah dan kadar gula darah terkontrol, serta dapat membaca dan menulis.

Instrumen peneilitian terdiri dari buklet yang berisi bacaan islami yang berisi kutipan dari ayat suci Al-Qur'an dan Hadits yang bertema tentang sehat dan sakit serta hikmah sakit sebanyak 12 halaman. Isi buklet bacaan islami telah dilakukan validitas konten oleh Dr. Opi Irawansyah, M.Pd.I. Adapun alat ukur skala penerimaan diri pasien dalam penelitian ini menggunakan kuesioner yang digunakan oleh (Puspita 2018). Kuesioner terdiri dari 15 item pertanyaan yang sudah dilakukan uji validitas dan realibilitas. Analisa data pada penelitian ini menggunakan analisa bivariat Sample paired T Test.

Prosedur pada penelitian ini meliputi pemilihan sample yang sesuai dengan kriteria inklusi dengan cara memberikan formulir isian data kepada pasien. Selanjutnya memberikan kuesioner penerimaan diri kepada sample penelitian terpilih sebagai nilai pre-test. Tahap berikutnya adalah memberikan buklet bacaan islami kepada sample penelitian untuk dibaca selama proses hemodialisis dan buklet dibawa pulang oleh pasien setelah selesai hemodialisis dengan harapan buklet dapat dibaca kembali saat di rumah. Pada saat jadwal hemodialisis selanjutnya, maka peneliti memberikan kuesioner penerimaan diri kembali sebagai nilai post-test setelah pemberian intervensi buklet bacaan islami. Pada tahap akhir penelitian, buklet bacaan islami juga diberikan kepada semua pasien hemodialisis yang tidak menjadi sample penelitian.

\section{Hasil dan Pembahasan \\ Karakteristik Responden}

Karakteristik responden pada penelitian ini adalah jenis kelamin, lama menjalani hemodialysis, tingkat pendidikan, dan usia. Karakteristik responden penelitian digambarkan dalam table 1 .

\section{Tabel 1. Karakteristik pasien hemodialisis berdasarkan Jenis Kelamin, lama waktu menjalani hemodialysis, tingkat pendidikan dan usia $(n=52)$}

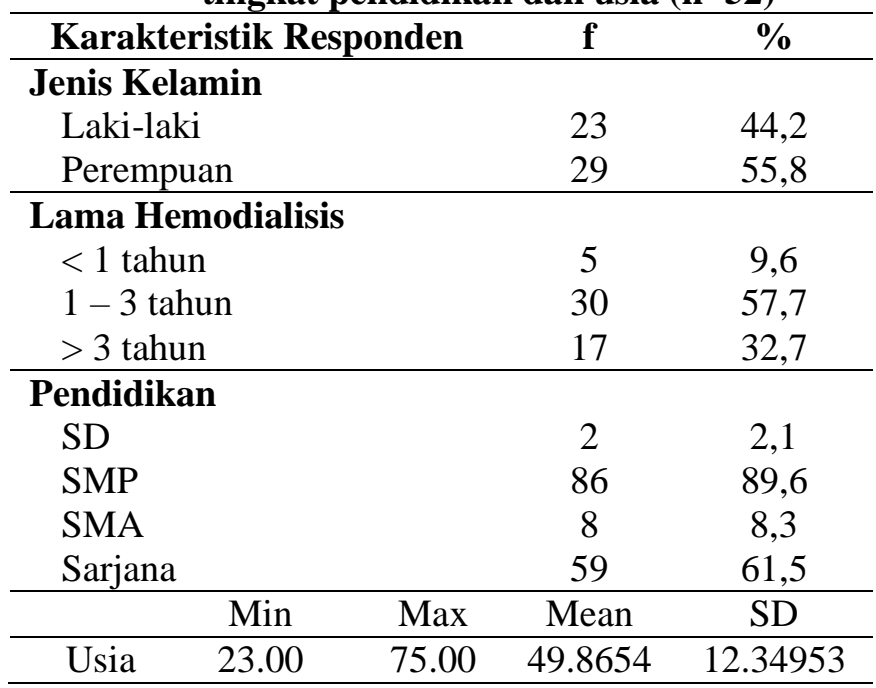

Berdasarkan tabel 1 diketahui bahwa pasien gagal ginjal yang menjalani hemodialisis di RSI 
Faletehan Health Journal, 7 (3) (2020) 170-176

www. journal.Ippm-stikesfa.ac.id/ojs/index.php/FHJ

ISSN 2088-673X | 2597-8667

Fatimah Cilacap sebagian besar berjenis kelamin perempuan $(55,4 \%)$, lama waktu pasien menjalani hemodialysis dalam rentang $1-3$ tahun $(57,7 \%)$, berpendidikan Sekolah Dasar $(46,2 \%)$ dan rerata usia adalah 49,86 tahun dengan usia termuda 23 tahun dan tertua 75 tahun.

Data hasil penelitian ini menunjukan bahwa berdasarkan jenis kelamin, pasien gagal ginjal yang menjalani hemodialisis di RSI Fatimah Cilacap terbanyak adalah jenis kelamin perempuan. Hal ini sejalan dengan penelitian (Rustandi, Tranado, and Pransasti 2018) yang menyatakan hasil penelitiannya menggambarkan distribusi jenis kelamin pasien CKD yang menjalani hemodialisis di RSUD Dr. M. Yunus Bengkulu tahun 2016, menunjukkan lebih dari sebagaian responden $(61,2 \%)$ memiliki jenis kelamin Perempuan. Hasil penelitian ini tidak sejalan dengan penelitian (Lathifah, 2016) yang menyataan pada hasil penelitiannya bahwa karakteristik jenis kelamin pada kelompok kasus dan kontrol paling banyak berjenis kelamin laki-laki yaitu 26 orang $(65 \%)$ dan 24 orang (60\%). Budiarto dan Anggraeni (2002) menjelaskan bahwa setiap penyakit dapat menyerang manusia baik laki-laki maupun perempuan, tetapi pada beberapa penyakit terdapat perbedaan frekuensi antara laki-laki dan perempuan.

Berdasarkan usia, hasil penelitian ini menunjukan bahwa usia pasien gagal ginjal yang menjalani hemodialisis di RSI Fatimah pada rentang 23 tahun - 75 tahun denga rerata usia 49,86 tahun. Hal ini sejalan dengan penelitian Agus dan Pranowo (2018) yang meneliti karakteristik pasien gagal ginjal menjalani hemodialisis di RSUD Cilacap dimana ditemukan hasil pasien gagal ginjal yang menjalani hemodialisis paling banyak pada rentang usia 15 - 64 tahun dengan usia rata - rata pasien gagal ginjal yang menjalani hemodialisis adalah 49,4 tahun. Hal ini juga sejalan dengan penelitian yang dilakukan Hervinda, Novadian, dan Tjekyan (2014) yang menunjukkan dari 300 sampel penelitian yang berusia 50-59 tahun terlihat adanya peningkatan kejadian penyakit ginjal kronik seiring dengan bertambahnya usia.

Setelah usia 30 tahun, ginjal akan mengalami atropi dan ketebalan kortek ginjal akan berkurang sekitar 20\% setiap dekade. Perubahan lain yang akan terjadi seiring dengan bertambahnya usia berupa penebalan membran basal glomerulus, ekspansi mesangium glomerular dan terjadinya deposit protein matriks ekstraselular sehingga menyebabkan glomerulosklerosis (Budiarto dan Anggraeni, 2002) menambahkan bahwa pada hakikatnya suatu penyakit dapat menyerang setiap orang pada semua golongan umur, tetapi ada penyakit-penyakit tertentu yang lebih banyak menyerang golongan umur tertentu. Penyakitpenyakit kronis mempunyai kecenderungan meningkat dengan bertambahnya umur, sedangkan penyakit-penyakit akut tidak mempunyai suatu kecenderungan yang jelas.

Lama atau durasi waktu pasien gagal ginjal yang menjalani hemodialisis di RSI Fatimah terbanyak adalah pada rentang $1-3$ tahun dengan frekuensi sejumlah 30 orang $(57,7 \%)$. Hasil penelitian ini sejalan dengan penelitian Agus dan Pranowo (2018) yang meneliti karakteristik pasien gagal ginjal menjalani hemodialisis di RSUD Cilacap dimana pasien gagal ginjal yang menjalani hemodialisis di RSUD Kabupaten Cilacap paling banyak adalah $1,1-3$ tahun sebanyak 37 pasien (33\%). Adapun angka rata-rata lama menjalani hemodialisis pada pasien gagal ginjal yang menjalani hemodialisis di RSUD Kabupaten Cilacap adalah sebesar 2,6 tahun. Menurut Nurcahyati (2011), semakin lama pasien menjalani HD maka pasien semakin patuh untuk menjalani HD karena biasanya responden telah mencapai tahap menerima ditambah mereka juga kemungkinan banyak mendapatkan pendidikan kesehatan dari perawat dan juga dokter tentang penyakit dan pentingnya melaksanakan HD secara teratur bagi mereka.

Berdasarkan tingkat pendidikan, sebagian besar pasien gagal ginjal yang menjalani hemodialisis di RSI Fatimah adalah berpendidikan Sekolah Dasar dengan frekuensi sejumlah 24 orang (46,2\%). Hal ini dapat berpengaruh terhdap pengetahuan pasien tentang kesehatan. (Pradono dan Sulistyowati 2013) menyatakan analisis dari hasil penelitiannya bahwa adanya hubungan yang positif dan sangat signifikan antara tingkat pendidikan dengan status kesehatan setelah dikontrol dari pengaruh variabel pengetahuan tentang kesehatan lingkungan, dan perilaku hidup sehat. Hasil koefisien determinan diperoleh $50,41 \%$. Ini menunjukkan bahwa 50,4\% status kesehatan ditentukan oleh variasi tingkat pendidikan, dengan persamaan regresi $\hat{Y}=60,77+$ $1,91^{*}$ (tingkat pendidikan).

\section{Pengaruh Pemberian Buklet Bacaan Islami dengan Penerimaan Diri Pasien Hemodialisis}


Faletehan Health Journal, 7 (3) (2020) 170-176

www. journal.Ippm-stikesfa.ac.id/ojs/index.php/FHJ

ISSN 2088-673X | 2597-8667

Tabel 2. Pengaruh Pemberian Buklet Bacaan Islami dengan Penerimaan Diri Pasien Hemodialisis $(n=52)$

\begin{tabular}{|c|c|c|c|c|c|c|c|c|c|}
\hline \multicolumn{10}{|c|}{ Paired Samples Test } \\
\hline & & \multicolumn{5}{|c|}{ Paired Differences } & \multirow[t]{3}{*}{$\mathrm{t}$} & \multirow[t]{3}{*}{ df } & \multirow{3}{*}{$\begin{array}{l}\text { Sig. }(2- \\
\text { tailed) }\end{array}$} \\
\hline & & \multirow[t]{2}{*}{ Mean } & \multirow[t]{2}{*}{$\begin{array}{l}\text { Std. } \\
\text { Dev. }\end{array}$} & \multirow{2}{*}{$\begin{array}{l}\text { Std. } \\
\text { Error } \\
\text { Mean }\end{array}$} & \multicolumn{2}{|c|}{$\begin{array}{c}95 \% \text { Confidence Interval } \\
\text { of the Difference }\end{array}$} & & & \\
\hline & & & & & Lower & Upper & & & \\
\hline Pair 1 & $\begin{array}{l}\text { pre - } \\
\text { post }\end{array}$ & -7.28846 & 4.64984 & .64482 & -8.58299 & -5.99394 & -11.303 & 51 & .000 \\
\hline
\end{tabular}

Berdasarkan data tabel output paired samples test diatas, maka dapat diketahui bahwa nilai Sig.(2-tailed) adalah sebesar $0.000<0.05$, atau dengan kata lain H0 ditolak dan Ha diterima. Sehingga dapat disimpulkan bahwa ada perbedaan rata-rata skor penerimaan diri antara hasi pre test dan post test yang artinya ada pengaruh pemberian buklet bacaan islami dengan penerimaan diri pasien hemodialisis di RSI Fatimah Cilacap.

Hasil penelitian ini menunjukkan bahwa nilai rerata pre-test berada pada skor 41,80 dan nilai rerata post-test berada pada skor 49,09 dari nilai terendah kuesioner penerimaan diri 15 dan nilai tertinggi 60. Hal ini menunjukan bahwa penerimaan diri pasien hemodialisis secara umum belum optimal. Penerimaan diri pada penderita gagal ginjal adalah penerimaan terhadap fisik dan menerima peransosial secara baik sehingga ia merasa bahagia, gembira dan puas yang pada gilirannya memberikan rasa percayadiri yang besar. Hasil penelitian yang dilakukan di Romania menunjukkan bahwa penerimaan diri berhubungan negative dengan kecemasan psikologis dan somatik kecemasan serta otomatis pikiran negatif. Intervensi pada variabel ini melalui dukungan dapat menyebabkan untuk mengurangi kecemasan dan depresi, untuk mengubah gayamengatasi dan, secara implisit, untuk meningkatkan kualitas hidup pasien. (Paloș and Vîșcu, 2014) artinya penerimaan diri mempengaruhi tingkat kecemasan dan depresi hidup pasien.

Hasil observasi lapangan saat peneliti memberikan kuesioner pre test didapatkan hampir sebagian besar pasien hemodialisa tidak banyak bicara kepada peneliti atau pasien disebelahnya. Banyak dari pasien hemodialisa yang mempunyai tatapan mata yang kosong dan melamun selama proses hemodialisa. Hasil wawancara kepada keluarga pasien didapatkan hampir sebagian besar keluarga menyampaikan bahwa pasien hemodialisa mempunyai tingkat emosi yang tinggi dan sering marah tanpa alasan yang jelas saat melakukan hemodialisa ataupun saat di rumah. Reza (2016) mengemukakan bahwa respon pasien setiap orang dalam melakukan terapi hemodialisa berbeda-beda seperti akan merasa cemas akibat krisis situasional, ancaman, kematian dan tidak mengetahui hasil akhir dari terapi. Pasien hemodialisis di unit hemodialisa menunjukkan bahwa sebagian besar pasien mengalami penolakan terhadap penyakit yang dialami, mengisolasi diri, marah, tawar menawar dan depresi . Penderita gagal ginjal kronis juga mengalami gangguan psikis berupa sering melamun dan merasa tertekan dengan kondisi sakit yang dialaminya

Pengamatan peneliti saat pasien membaca booklet bacaan islami yang diberikan selama periode dilakukan hemodialisa, beberapa pasien hemodialisa meneteskan air mata dan sesekali menarik nafas dalam. Hal ini menjadi salah satu tanda bahwa telah terjadi masalah psikologi pada pasien yang menjalani hemodialisa. Menurut Andi (2012), kenyataan bahwa pasien GGK tidak bisa lepas dari hemodialisa sepanjang hidupnya menimbulkan dampak psikologis yang tidak sedikit. Kondisi ini menyebabkan terjadinya kehilangan sesuatu yang sebelumnya ada seperti kebebasan, pekerjaan dan kemandirian. Hal ini bisa menimbulkan gejala-gejala depresi yang nyata pada pasien gagal ginjal sampai dengan tindakan bunuh diri. Selain itu masalah ketergantungan hemodialisa juga berdampak pada masalah ekonomi karena hemodialisa pada umumnya 4-5 jam dan dilakukan 2-3 kali dalam seminggu sehingga membutuhkan biaya banyak dan menyebabkan beban pikiran pada keluarga.

Hasil tabulasi kuesioner penerimaan diri didapatkan beberapa item pernyataan yang terjadi peningkatan rerata nilai paling tinggi meliputi pernyataan "saya menerima keadaan diri saya" dan 
Faletehan Health Journal, 7 (3) (2020) 170-176

www. journal.Ippm-stikesfa.ac.id/ojs/index.php/FHJ

ISSN 2088-673X | 2597-8667

pernyataan "saya tetap percaya diri dalam segala keterbatasan saya". Hasil observasi lapangan saat peneliti memberikan kuesioner post-test saat jadwal hemodialisa berikutnya didapatkan sebagian besar pasien menyatakan buklet bacaan islami yang dibaca sangat bermanfaat dan pasien meminta ijin untuk memiliki buklet bacaan islami tersebut. Hal ini menunjukan buklet bacaan islami yang diberikan dapat menjadi salah satu dukungan informatif dan pemenuhan kebutuhan spiritual pasien yang pada akhirnya membantu penerimaan diri pasien. Zefry dan Purnama (2016) menyatakan adanya hubungan positif antara dukungan sosial dan penerimaan diri pada pasien hemodialisa. Dukungan sosial mempunyai berbagai macam jenis diantaranya adalah dukungan informatif mencakup pemberian nasehat, petunjuk-petunjuk dan saran serta umpan balik. Pemberian buklet bacaan islami dapat menjadi sebuah cara dalam memberikan informasi yang berhubungan dengan pemenuhan kebutuhan spiritual yang pada akhirnya dapat menurunkan kecemasan dan depresi serta membantu penerimaan diri pasien hemodialisa. Hal ini juga merupakan salah satu bagian dari terapi psikoreligius atau psikospiritual. Religio psychotherapy atau psikoterapi religius merupakan penyembuhan penyakit melalui hidup kejiwaan yang didasari pada nilai keagamaan, tetapi tidak bermaksud mengubah keimanan dan kepercayaan pasien melainkan membangkitkan kekuatan batin pasien untuk membantu proses penyembuhan bersama-sama terapi lainnya (Arifin 2009).

Pemberian buklet bacaan islami juga pada akhirnya dapat dijadikan salah satu terapi kognitif bagi pasien hemdodialisis dalam mengatasi masalah psikologisnya. Terapi kognitif merupakan suatu terapi yang dapat mengidentifikasi pemikiran-pemikiran negatif yang mendorong terjadinya perubahan hargadiri. Nevid, Rathus, dan Greene (2003) menjelaskan bahwa terapi kognitif efektif untuk mengatasi klien yang memiliki emosi negatif seperti ansietas dan depresi yang disebabkan oleh interpretasi yang keliru terhadap peristiwa-peristiwa mengganggu yang tidak berasal dari peristiwa-peristiwa mereka sendiri. Terapi kognitif efektif juga mampu meningkatkan harga diri klien.

\section{Simpulan}

Hasil penelitian menunjukkan bahwa buklet bacaan islami mampu meningkatkan penerimaan diri pasien gagal ginjal yang menjalani hemodialisis di RSI Fatimah Cilacap. Pemberian buklet bacaan islami dapat menjadi salah satu intervensi dalam pelayanan keperawatan untuk memberikan informasi yang berhubungan dengan pemenuhan kebutuhan spiritual yang pada akhirnya dapat menurunkan kecemasan dan depresi serta membantu penerimaan diri pasien hemodialisis. Hal ini juga merupakan salah satu bagian dari terapi psikoreligius atau psikospiritual. Religio psychotherapy cenderung disebut sebagai psikoterapi religius yaitu penyembuhan penyakit melalui hidup kejiwaan yang didasari pada nilai keagamaan

\section{Referensi}

Agus, Prasetyo, and S. Pranowo. 2018. "Prosiding STIKes Bakti Tunas Husada Tasikmalaya, Jawa Barat, Indonesia 21 April 2018." (April).

Andi. 2012. "Peran Perawat Ginjal Dalam Mengoptimalkan Kualitas Hidup Pasien Dialisis." Jakarta Nephrology Nursing Symposium.

Arifin, Isep Zainal. 2009. Bimbingan Penyuluhan Islam, Pengembangan Dakwah Melalui Psikoterapi Islam. PT. Raja Grafindo Persada.

Budiarto, Eko, and Dewi Anggraeni. 2002. "Pengantar Epidemiologi." EGC:Jakarta.

Dalman. 2013. Keterampilan Membaca. Raja Grafindo.

Elizabeth B. Hurlock. 1973. Adolescent Development. Tokyo: McGraw-Hill Kogakusha.

Hervinda, Sundari, Novadian Novadian, and Suryadi Tjekyan. 2014. "Prevalensi Dan Faktor Risiko Penyakit Ginjal Kronik Di RSUP Dr. Mohammad Hoesin Palembang." Majalah Kedokteran Sriwijaya 46(4):275-81.

Kusuma, A. 2013. "Self-Acceptance of Street Children." 1(1):119-24.

Lathifah A U. 2016. "Faktor Resiko Kejadian Gagal Ginjal Kronis Pada Usia Dewasa Di RSUD Dr. Muwardi.” (June):4-13.

Nevid, Jeffrey S., Spencer A. Rathus, and Beverly Greene. 2003. Abnormal Psychology in a Changing World (5th Ed.).

Nurcahyati, Sofiana. 2011. Analisis Faktor-Faktor Yang Berhubungan Dengan Kualitas Hidup Pasien Gagal Ginjal Kronik Yang Hemodialisis Di RSI Fatimah Cilacap Dan Rumah Sakit Umum Daerah Banyumas.

Paloș, Ramona, and Loredana Vîșcu. 2014. 
"Anxiety, Automatic Negative Thoughts, and Unconditional Self-Acceptance in Rheumatoid Arthritis: A Preliminary Study." ISRN Rheumatology 2014(March):1-5. doi: $10.1155 / 2014 / 317259$.

Paramita, Ratri. 2013. "Pengaruh Penerimaan Diri Terhadap Penyesuaian Diri Penderita Lupus." Jurnal Psikologi Undip 12(1):1-8. doi: 10.14710/jpu.12.1.1-8.

Permatasari, Bunga. 2012. "Hubungan Antara Penerimaan Terhadap Kondisi Fisik Dengan Kecenderungan Anorexia Nervosa Pada Remaja Erempuan Di SMAN 1 Banjarmasin ( Relationship between Self-Acceptance on the Physical Condition of the Tendency of Anorexia Nervosa on Girls Adolescents In." Jurnal Psikologi Klinis Dan Kesehatan Mental 1(02):130-37.

Pradono, Julianty, and Ning Sulistyowati. 2013. "Hubungan Antara Tingkat Pendidikan, Pengetahuan Tentang Kesehatan Lingkungan, Perilaku Hidup Sehat Dengan Status Kesehatan." Buletin SPenelitian Sistem
Kesehatan.

Puspita, Restin Dwi. 2018. "HUBUNGAN ANTARA SELF EFFICACY DENGAN PENERIMAAN DIRI PADA PASIEN PENYAKIT JANTUNG." 10(2):1-15.

Reza, Iredho Fani. 2016. "Implementasi Coping Religious Dalam Mengatasi Gangguan FisikPsikis-Sosial-Spiritual Pada Pasien Gagal Ginjal Kronik.” Intizar 22(2):243. doi: 10.19109/intizar.v22i2.940.

Rustandi, Handi, Hengky Tranado, and Tinalia Pransasti. 2018. "Faktor-Faktor Yang Mempengaruhi Kualitas Hidup Pasien Chronic Kidney Disease Yang Menjalani Hemodialisis Di Ruang Hemodialisis.” Jurnal Keperawatan Silampari 1(2):32-46. doi: 10.31539/jks.v1i2.8.

Tarigan, Author, and Henry Guntur. 2011. "Pengajaran Kosakata." 1989.

Zefry, Muhammad, and Wahyu Purnama. 2016. "Dukungan Sosial Dengan Penerimaan Diri Pada Penderita Gagal Ginjal." Journal Psychology and Humanity. 